\title{
SYNERGISTIC EFFECTS OF SOME ALTERNATIVE SWEETENERS ON THE UNPLEASANT ATTRIBUTES OF STEVIA SWEETENER AND ITS APPLICATION IN SOME FRUIT DRINKS
}

\author{
Mona, I. Massoud ${ }^{1}$ \& Wafaa, A. Amin ${ }^{2}$ \\ ${ }^{1}$ Sugar Crops Research Institute, Agric. Research Center, EI Sabahia, Alexandria, Egypt. \\ ${ }^{2}$ Food Research Technology Institute, Agric. Research Center, EI Sabahia, Alexandria, Egypt.
}

\begin{abstract}
Stevia sweetener is considered as intensively sweet. In addition, it has also a bitter taste character and an undesirable aftertaste .To improve these attributes, stevia sweetener was combined with other sweeteners (sucrose, fructose, sorbitol and acesulfame K) to study the advantages of the synergistic effects that occur as a function of sweetener combinations. Five single sweetener solutions and 13 blends ( 6 binary; 4 tertiary and 3 quaternary) were tested at concentrations expected to be equivalent in intensity with $10 \%$ sucrose. Six blends were selected among the thirteen blend sweeteners to figure out their influences on the organoleptic attributes and some physico-chemical properties of the natural fruit drink (apple, orange and mango) after preparation and during storage. Results showed that bitterness and bitter after taste (AT) of stevia sweetener disappeared by the addition of sucrose and fructose in a ratio of $2: 1: 1$ (stevia : fructose : sucrose). Quaternary blends of stevia sweetener with fructose, sorbitol and sucrose(2 $: 1: 1: 1)$ may enhance and /or minimize certain stevia sweetener character and also gave the higher score of sweetness, flavour, overall acceptability and absence of bitterness compared with those of other sweetener blends. The aforementioned blend of sweeteners had the highest score of organoleptic attributes when it was applied in apple, orange and mango natural drinks. Storage at $5 \pm 2^{\circ} \mathrm{C}$ for four months did not affect considerably the physicochemical characteristic of the natural fruit drinks under investigation. Stevia sweetener may be combined with other sweeteners resulting in a synergistic effect of blends that provide good taste profiles and aftertaste and might be advantageous for diabetics and those over weight or those obese subjects as well.
\end{abstract}

Keywords: synergistic effect, stevia sweetener, alternative sweeteners, unpleasant attributes, natural drinks, storage.

\section{INTRODUCTION}

Consumer trends clearly indicate significant increases in consumption of reducedcalorie food and beverages. High potency sweeteners afford an opportunity to reducedcalorie products that may satisfy the nutrition conscious consumer (Wiet \& Beyts, 1992). Artificial sweeteners are added to a wide variety of food, drinks, drugs and hygienic products. As many artificial sweeteners are combined in today's products, the carcinogenic risk of a single substance is difficult to asses (Weihrauch \& Diehl, 2004). Natural sweeteners have been met with growing interest due to ban of some artificial sweeteners on the basis of being human carcinogen. Geuns (2003) reported that, the natural stevia sweetener extracted from Stevia rebaudiana Bertoni leaves, is a high intensity sweetener that tastes about 300 times sweeter than sucrose $(0.4 \%$ solution $)$. Leaf yields of $3000 \mathrm{~kg} / \mathrm{ha}$ with a stevioside concentration of $105 \mathrm{mg} / \mathrm{g}$ have been achieved in Canada.This is equivalent to 66.2 tonnes per hectare of sugar (Brandle \& Rosa 2003). In 1999, the joint FAD/WHO Expert Committee on Food Additives(JECFA) clearly stated that there was no indication of carcinogenic potential of stevioside (WHO, 1999). An acceptable daily intake (ADI) of $7.9 \mathrm{mg}$ stevioside $/ \mathrm{kg}$ body weight was suggested by Xili et al. (1992). Moreover, Huxtable (2002) and Geuns $(2002,2003)$ reported that stevioside, a natural material, is safe when used as a sweetener and the beneficial effect of the use of stevioside would rather be due to the substitution of sucrose in the food by a non-carcinogenic substance. Stevioside was reported to have many medical effects, it is a 
well-tolerated and effective compound that may be considered as an alternative or supplementary therapy for patients with hypertension (Chan et al., 2000); it acts directly on pancreatic beta cells to secrete insulin (Jeppesen et al., 2000). The advantages of stevioside as a dietary supplement for human subjects are manifold. It is stable in neutral or acidic aqueous solutions at $60^{\circ} \mathrm{C}$ or $100^{\circ} \mathrm{C}$ (Moussa et al., 2003) and it is a non-calorific (Kim et al., 2002). Also, it maintains good dental health by reducing the intake of sugar and opens the possibility for use by diabetic and phenylketonuria patients and obese persons (Geuns, 2003). The main disadvantages of using stevia as a sweetener are relating to their exhibits as a persistent aftertaste, with bitterness and astringency (Cardello et al., 1999, Moussa et al., 2003).

Addition of sucrose, fructose or glucose improves the organoleptic quality of stevioside (Kinghorn, 2002). Sweeteners are often used in combination to provide certain sensory properties and to take advantage of the synergism that occurs with certain sweetener combinations (Dziezak, 1987, Gelardi, 1987). Mixtures of certain sweeteners have been reported to produce a total sweetness intensity that is greater than the theoretical sum of the sweetening effects of the individual components of the mixture (Frank et al., 1989). When one sweetener is combined with other sweetener (s), it may produce a synergistic sweetening effect (Schiffman et al.,1995). Acesuflame-K is a high-intensive sweetener that is 200 times sweeter than sugar with a bitter taste, is safe for human consumption (Lipinski,1986) and has synergistic properties with other nonnutritive and nutritive sweeteners (Pszczola, 2003). Stevia may be combined with low caloric sweeteners resulting in a synergistic blend that improved taste profiles. Such blends also can provide economic and stability advantages (Anderson \& Young, 2002, Pszczola, 2003).

The objective of the present work is to study the possibility of improving and over coming the problem of undesirable aftertaste attributes of stevia sweetener and to maximize the use of natural sweeteners. Therefore, five sweeteners: three nutritive sweeteners (sucrose, fructose and sorbitol) and two non nutritive sweeteners (stevia sweetener and acesulfame $\mathrm{K}$ ) were used to investigate their organoleptic profile either individually or as 13 mixtures ( 6 binary, 4 tertiary and 3 quaternary) in equi-sweet concentration to $10 \%$ sucrose. Also, the synergistic effects among these mixtures on the taste quality of stevia sweetener were evaluated.

Some of the aforementioned sweeteners were selected to be applied in some natural fruit drinks. The effect of using these selective mixtures of sweeteners on the organoleptic attributes of some physico-chemical properties of natural fruit drinks (apple, orange and mango) was performed.

\section{MATERIALS AND METHODS}

\section{Materials:}

Alternative sweeteners, namely sucrose and sorbitol were purchased from El Nasr Pharmaceutical Chemical Co. Cairo, Egypt. Fructose was obtained from Park Scientific Limited Northampton; U.K. Stevia sweetener was extracted from Stevia rebaudiana leaves cultivated in El-Sabahia station (A.R.C) Alexandria,Egypt. Then, it was purified and crystallized as described by Hassan et al. (2002). Acesulfame K was obtained from Hoechst, A.G. Frankfurt, FRG. Ascorbic acid was obtained from AWA Chemical Co. (Great Britain), $\beta$ carotene 10\% CWS (E 160 a) manufactured by Roche AG Dissein, Switzerland. Sodium benzoate obtained from El Nasr Pharmaceutical Chemical Co. Egypt. Colour and flavour extracts from Delta Aromatic International Co. 439, Pyramids, Giza, Egypt. Natrium carboxymethylcellulose. Walocel CRT 30000 PA was obtained from United Food Industries, $6^{\text {th }}$ October city, Egypt.

Fruit drinks were obtained as follows: natural mango pulp, $16^{\circ}$ Brix from Cairo Agro. Processing Company, Egypt. Pasteurized, concentrated orange juice $66^{\circ}$ Brix, from El Marwa Food Industries, $6^{\text {th }}$ of October City and natural concentrated apple juice $70^{\circ}$ Brix, from Delta Aromatic International Co. 439 Pyramids, Giza, Egypt.

\section{Methods:}

Sweetener solutions: Five food grade sweeteners were employed in this study : two sugars (sucrose and fructose); sorbitol as polyhydric alcohols, stevioside as terpenoid glycosides and acesulfame $\mathrm{K}$ as $\mathrm{N}$-sulfonylamides. Five single sweetener solutions and 13 blends (6 binary; 4 tertiary and 3 quaternary) were tested at a concentration expected to be equiva- 
lent in intensity with $10 \%$ sucrose. Table (1) lists the abbreviations used for each sweetener, concentrations and ratios for each sweetener blend solution.

Table 1: Concentrations and ratios of tested sweeteners

\begin{tabular}{lc}
\hline \multicolumn{1}{c}{ Sweetener } \\
\hline Single: & Concentration \% \\
Sucrose (Suc.) & 10.000 \\
Stevia sweetener (Ste.) & 00.062 \\
Fructose (Fru.) & 06.640 \\
Sorbitol (Sor.) & 13.330 \\
Acesulfame K (Ace.) & 00.066 \\
\hline Binary: & (Ratio) \\
Ste. / Suc. & $1: 1$ \\
Ste. / Suc. & $2: 1$ \\
Ste. / Fru. & $1: 1$ \\
Ste. / Fru. & $2: 1$ \\
Ste. / Sor. & $1: 1$ \\
Ace./ Suc. & $1: 1$ \\
\hline Tertiary: & \\
Ste. / Fru. / Suc. & $2: 1: 1$ \\
Ste. / Fru. / Suc. & $2: 1.4: 0.6$ \\
Ste. / Sor. / Suc. & $2: 1: 1$ \\
Ste. / Sor. / Suc. & $2: 1.4: 0.6$ \\
\hline Quaternary: & \\
Ste. / Fru. / Sor. / Suc. & $2: 1: 1: 1$ \\
Ste. / Fru. / Sor. / Suc. & $2: 1: 0.6: 0.4$ \\
Ace. / Fru. / Sor. /Suc. & $2: 1: 1: 1$ \\
\hline
\end{tabular}

Sensory protocol of the sweetener solutions: Twelve trained panelists (males and females) aged $48 \pm 12$ years were selected after exposing to a variety of sweetener prior to the study as described by Wiet \& Beyts (1992). The panelists were asked to judge the samples for five attributes profile including [sweetness, bitterness, residual aftertaste: sweet after taste (sweet. AT), bitter (non-sweet) and aftertaste (bitter AT) astringency AT]. The residual aftertaste was measured about $20 \mathrm{sec}$ after swallowing. The scale used was rated from zero to 10 in which zero means the absence of the attribute while 10 means that the attribute is extremely intense. Sample size of each solution $(10 \mathrm{ml})$ was served in cooled plastic cups. The different samples were presented in random order at room temperature $\left(22 \pm 2^{\circ} \mathrm{C}\right)$.

Preparation of fruit drinks: Fruit drinks were prepared in Mansour for Manufacturing and Distribution Group (Siclam Factory) by mixing all ingredients as shown in Table (2). Sweeteners were prepared for the substitution of sucrose in fruit drinks . The amount of each sweetener was calculated according to its sweetness equivalent. The relative sweetness of fructose, sorbitol, stevia sweetener and acesulfame $\mathrm{K}$ are $1.5,0.6,200$ and 150 time as sucrose. The fruit drink was filled into glass containers of $200 \mathrm{ml}$ capacity. The containers were closed tightly and autoclaved (at $105^{\circ} \mathrm{C}$ for 15 min, 1.5 bar). Then, the glass containers were cooled and stored for 4 months at $5 \pm 2{ }^{\circ} \mathrm{C}$ in refrigerator. All samples were analyzed for chemical analysis every two months.

Chemical Analysis: The fruit drinks were analyzed for titratable acidity according to AOAC (1990); the $\mathrm{pH}$ was measured using Beckman $\mathrm{pH}$ meter (pH MVx 100 Beckman. USA)following the procedure of AOAC (1990), total sugars content was determined as described by Sadasivam \& Manickam (1992) and total soluble solids were measured using hand referactometer AtagaN-1E. made in Japan. Brookfield viscometer HP was util-

Table 2: Percentage of ingredients used in preparing fruit drinks

\begin{tabular}{lrrr}
\hline \multicolumn{1}{c}{ Ingredients \% } & \multicolumn{3}{c}{ Natural drink } \\
\cline { 2 - 4 } & Apple & Mango & Orange \\
\hline Pulp or concentrate & 5.00 & 15 & 6.5 \\
Sucrose or alternative sweeteners* & 11.00 & 12 & 12 \\
Natrium carboxymethylcellulose & - & 0.33 & - \\
Citric acid & 0.30 & 0.14 & 0.2 \\
$\beta$-carotene 10\% CWS & - & 0.005 & 0.003 \\
Sodium benzoate & 0.01 & 0.01 & 0.01 \\
Ascorbic acid & 0.03 & 0.03 & 0.04 \\
Flavouring agent & 0.04 & 0.03 & 0.03 \\
Caramel colour & 0.001 & - & - \\
Water & 83.619 & 72.455 & 81.217 \\
\hline
\end{tabular}

* Alternative sweeteners: The selected sweetener blend solutions are shown in Table (1). 
ized to estimate the homogenized mango drink (Rangana, 1977). Ostwald instrument was used to determine the relative viscosity of apple and orange drinks as outlined by Matz (1962).

Organoleptic properties: Taste (sweetness), bitterness, flavour and overall acceptability of the three fruit drinks were assessed by 15 panelists of Crops Res. Inst. and Food Technol. Laboratory, Food Technol. Res. Inst. Agric. Res.Center, Sabahia Station, Alexandria, using a 10 hedonic scale as mentioned by Watts et al. (1989).

Statistical analysis: Standard deviation of the results and analysis of variance were calculated using the methods described by Steel \& Torrie (1980).

\section{RESULTS AND DISCUSSION}

Table (3) shows the organoleptic attributes of the single and blended sweetener solutions. The four sweetener solutions had sweetness scores higher than suc. The sweetness can be ranked in descending order as follows: sor., fru., ste. then ace.. Stevia sweetener (the natural sweetener) and ace.(the artificial sweetener) were the only two single solutions that had bitterness.

In case of the aftertaste attribute, ste. and ace. had the highest score of sweetness. The sweetness of sucrose decreased over time when consumed intermittently in water (Schiffman et al., 1995). The ste. solution had a high score of bitterness aftertaste (bitter AT) and it was very far from the three other solutions that had a very weak bitter AT. The suc. solution was the only sweetener solution that had no bitter AT. Astringency aftertaste (astringency AT) was appeared only in ste. and ace. From the previous discussion, it was clear that, ste. solutions had the highest score of bitterness, bitter AT and astringency AT. As the objective of the present study was to improve the unpleasant taste quality attributed to stevioside and to maximize the use of the natural and nonnutritive sweeteners, it was necessary to study the synergistic effect of blending mixtures of some sweeteners. Von Rymon (1997); Hutteau et al. (1998) and Schiffman et al. (2003) reported that, sweetener blends became important in the production of foods and beverages as synergistic taste enhancement, sweeteners profile modifications offer advantages over the use of single sweetener as well as the economical and stability advantages.

From the six binary blends, ste./suc. (2:1) was neglected because it had the highest score of bitter and bitter AT., also this blend was the only binary blend that had astringency AT. It was noticed that, ste./suc. (1:1). had similar score attributes of bitter and bitter AT with ace./suc. (1:1). The undesirable attributes that appear with acesulfame $\mathrm{K}$, the artificial sweetener which was already used in commercial

Table 3: Descriptive mean ratings for single and blended sweetener solutions equi-sweet to $10 \%$ sucrose*

\begin{tabular}{|c|c|c|c|c|c|c|}
\hline $\begin{array}{c}\text { Sweetener or } \\
\text { Sweetener blend }\end{array}$ & Ratio & Sweetness & Bitterness & Sweetness & $\begin{array}{c}\text { Aftertaste } \\
\text { Bitterness }\end{array}$ & Astringency \\
\hline Suc. & & $8.50^{\text {cde }}$ & $0.0^{\mathrm{e}}$ & $0.71^{\mathrm{de}}$ & $0.0^{\mathrm{c}}$ & $0.0^{\mathrm{b}}$ \\
\hline Ste. & & $8.87^{\text {bcd }}$ & $4.08^{\mathrm{a}}$ & $4.83 \mathrm{a}$ & $2.17^{\mathrm{b}}$ & $0.92^{\mathrm{a}}$ \\
\hline Fru. & & $8.70^{\text {cd }}$ & $0.0^{\mathrm{e}}$ & $0.63^{\mathrm{de}}$ & $0.25^{\mathrm{c}}$ & $0.0^{\mathrm{b}}$ \\
\hline Sor. & & $8.63^{\mathrm{cd}}$ & $0.0^{\mathrm{e}}$ & $1.08^{\mathrm{cd}}$ & $0.25^{\mathrm{c}}$ & $0.0^{\mathrm{b}}$ \\
\hline Ace. & & $8.59^{\text {cde }}$ & $3.21^{\mathrm{b}}$ & $4.72^{\mathrm{a}}$ & $0.21^{\mathrm{c}}$ & $0.67^{\mathrm{a}}$ \\
\hline Ste./Suc. & $1: 1$ & $8.21^{\mathrm{fe}}$ & $1.21^{\mathrm{d}}$ & $0.33^{\mathrm{de}}$ & $0.58^{\mathrm{c}}$ & $0.0^{\mathrm{b}}$ \\
\hline Ste./Suc. & $2: 1$ & $7.92^{\mathrm{fg}}$ & $3.0^{\mathrm{b}}$ & $2.17^{\mathrm{b}}$ & $2.25^{\mathrm{a}}$ & $0.33^{\mathrm{b}}$ \\
\hline Ste./Fru. & $1: 1$ & $8.75^{\text {cd }}$ & $0.42^{\mathrm{e}}$ & $0.58^{\mathrm{de}}$ & $0.17^{\mathrm{c}}$ & $0.0^{\mathrm{b}}$ \\
\hline Ste./Fru. & $2: 1$ & $7.50^{\mathrm{g}}$ & $1.29^{\mathrm{d}}$ & $1.92^{\mathrm{bc}}$ & $0.79^{\mathrm{bc}}$ & $0.0^{\mathrm{e}}$ \\
\hline Ste./Sor. & $1: 1$ & $8.21^{\mathrm{fe}}$ & $2.21^{\mathrm{c}}$ & $0.92^{\mathrm{de}}$ & $0.71^{\mathrm{c}}$ & $0.0^{\mathrm{b}}$ \\
\hline Ace./Suc. & $1: 1$ & $7.92^{\mathrm{fg}}$ & $1.21^{\mathrm{d}}$ & $1.00^{\mathrm{de}}$ & $0.58^{\mathrm{c}}$ & $0.0^{\mathrm{b}}$ \\
\hline Ste./Fru./Suc. & $2: 1: 1$ & $9.17^{\mathrm{bc}}$ & $0.0^{\mathrm{e}}$ & $0.17^{\mathrm{de}}$ & $0.0^{\mathrm{c}}$ & $0.0^{\mathrm{b}}$ \\
\hline Ste./Fru./Suc. & $2: 1.4: 0.6$ & $7.79^{\mathrm{fg}}$ & $1.79^{\mathrm{c}}$ & $1.00^{\mathrm{de}}$ & $0.17^{\mathrm{c}}$ & $0.17^{\mathrm{b}}$ \\
\hline Ste./Sor./Suc. & $2: 1: 1$ & $9.0^{\mathrm{bcd}}$ & $0.0^{\mathrm{e}}$ & $0.33^{\mathrm{de}}$ & $0.0^{\mathrm{c}}$ & $0.0^{\mathrm{b}}$ \\
\hline Ste./Sor./Suc. & $2: 1.4: 0.6$ & $9.21^{\mathrm{b}}$ & $2.21^{\mathrm{c}}$ & $1.17^{\mathrm{cd}}$ & $0.79^{\text {bc }}$ & $0.0^{\mathrm{b}}$ \\
\hline Ste./Fru./Sor./Suc. & 2: $1: 0.6: 0.4$ & $7.79^{\mathrm{fg}}$ & $0.21^{\mathrm{e}}$ & $0.17^{\mathrm{de}}$ & $0.0^{\mathrm{c}}$ & $0.0^{\mathrm{b}}$ \\
\hline Ste./Fru./Sor./Suc. & $2: 1: 1: 1$ & $9.79^{\mathrm{a}}$ & $0.0^{\mathrm{e}}$ & $0.17^{\mathrm{de}}$ & $0.0^{\mathrm{c}}$ & $0.0^{\mathrm{b}}$ \\
\hline Ace./Fru./Sor./Suc. & $2: 1: 1: 1$ & $8.94^{\text {bcd }}$ & $0.42^{\mathrm{e}}$ & $0.17^{\text {de }}$ & $0.13^{\mathrm{c}}$ & $0.0^{\mathrm{b}}$ \\
\hline
\end{tabular}

*Means in a column that are not sharing the same letter are significantly different at $\mathrm{P} \leq 0.05$. 
processing, decreased when it was mixed with suc. (1:1). Horne et al. (2002) and Kuhn et al. (2004) mentioned that acesulfame $\mathrm{K}$ is an intense sweetener with a bitter taste. According to Ott et al. (1991), acesulfame K has a delayed bitter AT that is more intense and longer in duration than sucrose. Schiffman et al. (1985) noticed high variability in the intensity and quality of acesulfame $\mathrm{K}$ due to bitter and metallic side tastes.

By comparing ste./suc. (2:1) with ste./fru. (2:1) it was clear that fructose was the cause of reducing the score of bitterness from 3.0 to 1.29 and the score of bitter AT from 2.25 to 0.79 (Table 3). Also, the astringency AT was disappeared. Bitterness and bitter AT were increased by decreasing the ratio of ste. in blend ste. : fru. (1:1). According to Moussa et al. (2003), the aftertaste of stevia sweetener was a mixed taste of sweetness and bitterness. Attributes other than sweetness or any off flavour were slightly increased with higher concentration of stevia sweetener. Accordingly, blends ste./suc.(1:1) and ste./fru. (1:1) were selected from the binary blends, because they had the lowest attributes of bitterness, bitter AT. and no astringency AT. Schiffman et al. (1995) found that, sweeteners can be used in binary combination to take the advantage of their synergistic effects.

The organoleptic properties of the binary blends were improved by the addition of the third sweetener. Bitterness and bitter AT were disappeared by changing the blend from ste./fru. (2:1) to ste./suc./fru.(2:1:1). Also the degree of sweetness was increased. The same observation was noticed when sucrose was added to the blend ste./sor.(2:1). In this case, the degree of sweetness increased while both the bitterness and bitter AT decreased. The previous observation was found when the mixture contained sorbitol instead of fructose. The only exception was that no astringency AT was detected.

From the suggested quaternary combination blends, two were selected. The first was ste./fru./sor./suc. (2:1:1:1) that had the highest sweet taste and no bitter and bitter AT. The second was ace./fru./sor./suc. (2:1:1:1). As noticed from Table (3), blends stevioside sweetener with other alternative sweeteners reduced the unpleasant attributes that appear with stevioside only (Hanger et al., 1996).
From the aforementioned results, six blends were selected to apply during the manufacture of the natural fruit drinks (apple, orange and mango drinks). These blends were as follows: T1 [ste./suc. (1:1)], T2 [ste.:fru. (1:1)], T3 [ste./fru./suc. (2:1:1)], T4 [ste./ sor. /suc.(2:1:1)], T5 [ste./fru./sor./suc. (2:1:1:1)] and T6 [ace./fru./sor./suc. (2:1:1:1)].

Sensory evaluation of natural fruit drinks: As a matter of fact, organoleptic properties are the final guide to the quality from the consumer point of view. Therefore, the application of the selected nutritive and non-nutritive sweetener blends was carried out on apple, orange and mango natural drinks to investigate their effects on the taste quality (sweetness, bitterness), flavour and the overall acceptability (Table 4).

The data indicated that all drinks prepared and sweetened with quaternary sweetener blends (T5), had the higher score of sweetness, flavour, overall acceptability and absence of bitterness compared with those which contained other sweetener blends.

Statistical analysis justified the previous finding. In the three fruit drinks, it was observed that, increasing the number of sweeteners in the blend led to increase the score of sweet taste and decrease the score of bitterness attribute. These data are in agreement with the results obtained by Askar (1988) and Abou Zaid et al. (1990) who found that, the best sweetening formula in nectar production was obtained by using a combination of sweeteners mixture of fructose or sorbitol with acesulfame $\mathrm{K}$ and aspartame.

Orange drink had the higher score of bitterness, followed by apple and mango drinks. Bitter taste appeared in all samples of orange drinks containing the different sweeteners as well as the control drink.. This means that the kind of fruit drink affected the presence of bitter taste. It was clear that the addition of ste. was the cause of bitterness, while the addition of sorbitol lowered the score of this attribute. No statistical differences were found between the bitterness intensity of the six sweetener blends and also the control of apple and mango. Barwal et al. (2002) reported that with the increase in the proportion of sorbitol sweetness, the sensory score for colour, body and flavour increased. Generally, bitterness of apple and mango drink samples was very low. 
Table 4: Sensory evaluation of natural fruit drinks (apple, mango and orange)*

\begin{tabular}{llllllll}
\hline Properties & Control & T1 & T2 & T3 & T4 & T5 & T6 \\
\hline Taste & & & & & & & \\
Sweetness & & & & & & & \\
Apple & $9.79^{\mathrm{a}}$ & $7.88^{\mathrm{c}}$ & $8.33^{\mathrm{bc}}$ & $8.46^{\mathrm{bc}}$ & $8.14^{\mathrm{c}}$ & $9.17^{\mathrm{ab}}$ & $9.09^{\mathrm{ab}}$ \\
Mango & $9.88^{\mathrm{a}}$ & $7.75^{\mathrm{cd}}$ & $7.92^{\mathrm{c}}$ & $7.08^{\mathrm{d}}$ & $9.13^{\mathrm{ab}}$ & $9.33^{\mathrm{ab}}$ & $8.92^{\mathrm{b}}$ \\
Orange & $7.63^{\mathrm{abc}}$ & $7.13^{\mathrm{bc}}$ & $6.92^{\mathrm{c}}$ & $7.17^{\mathrm{bc}}$ & $7.42^{\mathrm{bc}}$ & $8.50^{\mathrm{a}}$ & $8.04^{\mathrm{ab}}$ \\
Bitterness & & & & & & & \\
Apple & 0.0 & 0.82 & 0.87 & 0.55 & 0.41 & 0.23 & 0.23 \\
Mango & 0.0 & 0.46 & 0.68 & 0.45 & 0.0 & 0.0 & 0.0 \\
Orange & $0.92^{\mathrm{c}}$ & $2.08^{\mathrm{a}}$ & $2.33^{\mathrm{a}}$ & $2.07^{\mathrm{a}}$ & $2.00^{\mathrm{ab}}$ & $0.68^{\mathrm{c}}$ & $1.08^{\mathrm{bc}}$ \\
Flavour & & & & & & & \\
Apple & 9.08 & 8.17 & 8.25 & 8.33 & 8.50 & 9.29 & 8.63 \\
Mango & 9.00 & 8.50 & 7.71 & 8.27 & 8.63 & 8.67 & 8.54 \\
Orange & $7.10^{\mathrm{e}}$ & $7.48^{\mathrm{cd}}$ & $7.63^{\mathrm{bc}}$ & $7.33^{\mathrm{de}}$ & $7.63^{\mathrm{bc}}$ & $8.00^{\mathrm{a}}$ & $7.75^{\mathrm{ab}}$ \\
Overall-acceptability & & & & & & & \\
Apple & $9.50^{\mathrm{a}}$ & $7.92^{\mathrm{c}}$ & $7.75^{\mathrm{c}}$ & $8.17^{\mathrm{bc}}$ & $8.33^{\mathrm{bc}}$ & $9.13^{\mathrm{a}}$ & $8.92^{\mathrm{ab}}$ \\
Mango & $9.17^{\mathrm{a}}$ & $8.25^{\mathrm{bc}}$ & $7.71^{\mathrm{c}}$ & $8.40^{\mathrm{bc}}$ & $8.92^{\mathrm{ab}}$ & $9.04^{\mathrm{ab}}$ & $8.58^{\mathrm{ab}}$ \\
Orange & $8.02^{\mathrm{a}}$ & $7.18^{\mathrm{c}}$ & $7.04^{\mathrm{c}}$ & $7.35^{\mathrm{bc}}$ & $7.47^{\mathrm{abc}}$ & $7.83^{\mathrm{ab}}$ & $7.37^{\mathrm{bc}}$ \\
\hline
\end{tabular}

*Means in column that are not sharing the same letter are significantly different at $\mathrm{P} \leq 0.05$.

T1: Ste./Suc. (1: 1) T4: Ste./ Sor./ Suc. (2: 1: 1)

T2: Ste./ Fru. (1:1) T5: Ste./ Fru./ Sor./ Suc. (2: 1: 1: 1)

T3: Ste./ Fru./Suc. (1: 2:1) T6: Ace./ Fru./ Sor./ Suc. (2: 1:1:1)

No significant $(\mathrm{P} \leq 0.05)$ effect could be traced for flavour of apple and mango prepared and sweetened with different sweetener blends as compared to their counterparts sweetened with sucrose. On the contrary, all the tested samples of the orange drink had flavour score higher than control and they were significantly different in this respect. Adding any sweetener as a substitution of sucrose in orange drink resulted in slight increase in the score of flavour. Nahon et al. (1996) showed that when sucrose was replaced by intense sweeteners in strawberry drinks, the aroma attribute increased. While, Matysiak \& Noble (1991) stated that fruitiness and sweetness persisted significantly longer in orange - flavoured the binary system than the tertiary. Moussa et al. (2003) found that the scores for flavour of anise, peppermint and lemonade beverage with stevia sweetener were higher than that with sucrose as a sweetener.

In the light of data presented here, the overall acceptability of fruit drinks sweetened with sweetener blends could be arranged in a descending order as follows: Apple fruit juice $\mathrm{T} 5>\mathrm{T} 6>\mathrm{T} 4>\mathrm{T} 3>\mathrm{T} 1>\mathrm{T} 2$, mango fruit drink $\mathrm{T} 5>\mathrm{T} 4>\mathrm{T} 6>\mathrm{T} 3>\mathrm{T} 1>\mathrm{T} 2$ and orange fruit drinks $\mathrm{T} 5>\mathrm{T} 4>\mathrm{T} 6>\mathrm{T} 3>\mathrm{T} 1>\mathrm{T} 2$.

Physico-chemical properties of apple, orange and mango natural drinks pre- pared with selected sweeteners: Tables (5), (6) and (7) summarize some of the physicochemical properties namely, $\mathrm{pH}$, titratable acidity, total soluble solids, total sugars and viscosity of apple, orange and mango natural drinks prepared with different sweeteners during the storage for 4 months at $5 \pm 2^{\circ} \mathrm{C}$.

It can be noticed that, the alternative sweeteners had no effect on the $\mathrm{pH}$ value. The data also indicated that, there were gradual decreases in the $\mathrm{pH}$ value for the three drinks and slight increase in titratable acidity was observed during storage period. Total soluble solids (T.S.S.) of all drinks were found to decrease as the ratio of the alternative sweeteners added increased as compared to fruit drinks containing sucrose only. This reduction in T.S.S. may be attributed to the quantities of the alternative sweeteners used. A similar observation was stated by Abou Zaid et al. (1990).

From the Tables(5), (6) and (7), it is clear that the storage period had no effect on all of the tested samples. Total sugars were $12.16,12.10$ and $11.55 \%$ for apple, orange and mango natural drink prepared with sucrose, respectively. It was obvious that replacing sucrose by the other blend sweeteners decreased the aforementioned figures of the three drinks. 
Table 5: Some physico-chemical properties of apple drink prepared with selected sweeteners during storage for 4 months at $5 \pm 2^{\circ} \mathrm{C}$

\begin{tabular}{|c|c|c|c|c|c|c|c|}
\hline \multirow{2}{*}{$\begin{array}{l}\text { Storage period } \\
\text { (months) }\end{array}$} & \multicolumn{7}{|c|}{ Sweetener or blend } \\
\hline & Control Suc & T1 & $\mathbf{T 2}$ & T3 & T4 & T5 & T6 \\
\hline \multicolumn{8}{|c|}{$\overline{\mathbf{p H}}$} \\
\hline Zero & 3.20 & 3.16 & 3.19 & 3.15 & 3.09 & 3.14 & 3.11 \\
\hline 2 & 3.09 & 3.05 & 3.11 & 3.11 & 3.09 & 3.11 & 3.09 \\
\hline 4 & 2.89 & 2.97 & 2.98 & 2.98 & 2.96 & 3.04 & 2.95 \\
\hline \multicolumn{8}{|c|}{ Titratable acidity (\%) } \\
\hline Zero & 0.34 & 0.36 & 0.34 & 0.34 & 0.34 & 0.35 & 0.34 \\
\hline 2 & 0.36 & 0.38 & 0.36 & 0.34 & 0.34 & 0.36 & 0.34 \\
\hline 4 & 0.37 & 0.38 & 0.36 & 0.36 & 0.38 & 0.36 & 0.35 \\
\hline \multicolumn{8}{|c|}{ Relative viscosity (Centi-poise) } \\
\hline Zero & 1.88 & 1.87 & 1.87 & 1.87 & 1.87 & 1.88 & 1.88 \\
\hline 2 & 1.90 & 1.87 & 1.87 & 1.88 & 1.88 & 1.88 & 1.88 \\
\hline 4 & 1.92 & 1.88 & 1.87 & 1.89 & 1.88 & 1.88 & 1.88 \\
\hline \multicolumn{8}{|c|}{ T.S.S. (\%) } \\
\hline Zero & 14.0 & 10.5 & 10.0 & 11.0 & 10.0 & 10.5 & 10.5 \\
\hline 2 & 14.0 & 10.5 & 10.0 & 11.0 & 10.0 & 10.5 & 10.5 \\
\hline 4 & 14.0 & 10.5 & 10.0 & 11.0 & 10.0 & 10.5 & 10.5 \\
\hline \multicolumn{8}{|c|}{ Total sugars $(\%)$} \\
\hline Zero & 12.16 & 8.65 & 6.73 & 8.06 & 6.33 & 7.05 & 6.99 \\
\hline 2 & 12.01 & 8.33 & 6.52 & 7.76 & 6.15 & 6.78 & 6.74 \\
\hline 4 & 11.19 & 8.18 & 6.35 & 7.65 & 6.11 & 6.71 & 6.69 \\
\hline
\end{tabular}

Table 6: Some physico-chemical properties of natural mango drink prepared with different sweeteners during storage for 4 months at $5 \pm 2^{\circ} \mathrm{C}$

\begin{tabular}{|c|c|c|c|c|c|c|c|}
\hline \multirow{2}{*}{$\begin{array}{c}\text { Storage period } \\
\text { (months) }\end{array}$} & \multicolumn{7}{|c|}{ Sweetener or blend } \\
\hline & Control Suc & T1 & $\mathbf{T 2}$ & T3 & T4 & $\mathbf{T 5}$ & T6 \\
\hline \multicolumn{8}{|c|}{ pH } \\
\hline Zero & 3.88 & 3.85 & 3.83 & 3.87 & 3.87 & 3.78 & 3.68 \\
\hline 2 & 3.78 & 3.72 & 3.71 & 3.71 & 3.79 & 3.77 & 3.65 \\
\hline 4 & 3.69 & 3.67 & 3.74 & 3.69 & 3.70 & 3.72 & 3.30 \\
\hline \multicolumn{8}{|c|}{ Titratable acidity (\%) } \\
\hline Zero & 0.21 & 0.21 & 0.22 & 0.21 & 0.21 & 0.22 & 0.22 \\
\hline 2 & 0.22 & 0.22 & 0.23 & 0.22 & 0.22 & 0.24 & 0.23 \\
\hline 4 & 0.24 & 0.27 & 0.26 & 0.23 & 0.23 & 0.26 & 0.25 \\
\hline \multicolumn{8}{|c|}{ Relative viscosity (Centi-poise) } \\
\hline Zero & 100 & 82 & 73 & 76 & 78 & 80 & 80 \\
\hline 2 & 102 & 82 & 75 & 76 & 78 & 82 & 82 \\
\hline 4 & 106 & 85 & 77 & 79 & 80 & 84 & 85 \\
\hline \multicolumn{8}{|c|}{ T.S.S. (\%) } \\
\hline Zero & 14.0 & 9.0 & 9.5 & 10.0 & 12.0 & 10.0 & 10.0 \\
\hline 2 & 14.0 & 9.0 & 9.5 & 10.0 & 12.0 & 10.0 & 10.0 \\
\hline 4 & 13.9 & 9.1 & 9.5 & 10.0 & 12.0 & 10.0 & 10.0 \\
\hline \multicolumn{8}{|c|}{ Total sugars (\%) } \\
\hline Zero & 11.55 & 8.19 & 6.64 & 7.67 & 6.44 & 7.18 & 7.10 \\
\hline 2 & 11.42 & 7.98 & 6.57 & 7.42 & 6.27 & 7.10 & 7.03 \\
\hline 4 & 10.65 & 7.79 & 6.30 & 7.29 & 6.20 & 6.84 & 6.75 \\
\hline
\end{tabular}

T1: Ste./ Suc. (1: 1)

T2: Ste./ Fru. (1: 1)

T3: Ste./ Fru./ Suc. (1: 2: 1)
T4: Ste./ Sor./ Suc. (2: 1: 1)

T5: Ste./ Fru./ Sor./ Suc. (2: 1: 1:1)

T6: Ace./ Fru./ Sor./ Suc. (2: $1: 1: 1)$ 
Table 7: Some physico-chemical properties of orange drink with selected sweeteners during storage for 4 months at $5 \pm 2^{\circ} \mathrm{C}$

\begin{tabular}{|c|c|c|c|c|c|c|c|}
\hline \multirow{2}{*}{$\begin{array}{l}\text { Storage period } \\
\text { (months) }\end{array}$} & \multicolumn{7}{|c|}{ Sweetener or blend } \\
\hline & Control Suc & T1 & $\mathbf{T 2}$ & T3 & T4 & T5 & T6 \\
\hline \multicolumn{8}{|c|}{ pH } \\
\hline Zero & 3.52 & 3.54 & 3.52 & 3.54 & 3.53 & 3.54 & 3.55 \\
\hline 2 & 3.51 & 3.50 & 3.49 & 3.49 & 3.42 & 3.50 & 3.50 \\
\hline 4 & 3.50 & 3.45 & 3.44 & 3.46 & 3.39 & 3.48 & 3.44 \\
\hline \multicolumn{8}{|c|}{ Titratable acidity (\%) } \\
\hline Zero & 0.36 & 0.40 & 0.40 & 0.38 & 0.37 & 0.37 & 0.37 \\
\hline 2 & 0.37 & 0.40 & 0.40 & 0.42 & 0.41 & 0.38 & 0.41 \\
\hline 4 & 0.39 & 0.42 & 0.42 & 0.44 & 0.45 & 0.40 & 0.44 \\
\hline \multicolumn{8}{|c|}{ Relative viscosity (Centi-poise) } \\
\hline Zero & 1.49 & 1.47 & 1.36 & 1.47 & 1.45 & 1.50 & 1.46 \\
\hline 2 & 1.51 & 1.66 & 1.49 & 1.47 & 1.52 & 1.54 & 1.48 \\
\hline 4 & 2.18 & 1.70 & 1.67 & 1.51 & 1.67 & 1.61 & 1.63 \\
\hline \multicolumn{8}{|c|}{ T.S.S. (\%) } \\
\hline Zero & 13.0 & 11.7 & 10.2 & 10.8 & 11.0 & 12.1 & 11.8 \\
\hline 2 & 13.0 & 12.0 & 10.2 & 10.7 & 11.0 & 12.1 & 11.7 \\
\hline 4 & 13.0 & 12.0 & 10.0 & 10.5 & 11.0 & 12.0 & 11.5 \\
\hline \multicolumn{8}{|c|}{ Total sugars (\%) } \\
\hline Zero & 12.10 & 9.01 & 8.16 & 7.92 & 7.29 & 7.27 & 7.32 \\
\hline 2 & 11.80 & 8.96 & 7.85 & 7.80 & 7.17 & 7.12 & 7.24 \\
\hline 4 & 11.22 & 8.54 & 7.70 & 7.49 & 7.02 & 6.95 & 7.00 \\
\hline
\end{tabular}

T1: Ste./ Suc. (1:1)

T4: Ste./ Sor./ Suc. (2: 1: 1)

T2: Ste./ Fru. (1: 1$)$

T5: Ste./ Fru./ Sor./ Suc. $(2: 1: 1: 1)$

T3: Ste./ Fru./ Suc. $(1: 2: 1)$

T6: Ace./ Fru./ Sor./ Suc. (2: 1: 1:1)

The high reduction in total sugars was a result of substitution of sucrose with low or non caloric sweeteners which in turn might be important for diabetics and those over weight or those obese subjects as well (Asker, 1988). Total sugars content was affected by the period of storage. There was a pronounced decrease in all samples especially in the control. Data regarding total sugars and T.S.S. are in-agreement with those of Askar (1988) and Abou Zaid et al. (1990).There were slight decreases in viscosity of mango or orange drink sweetened by a combination of any of the aforementioned sweeteners than sweetened with $100 \%$ sucrose.

From the aforementioned results it can be concluded that combining stevia sweetener with fructose, sorbitol and sucrose $(2: 1: 1: 1)$ may enhance and /or minimize certain sweetener character, mask its bitter after taste and its better in natural drinks

\section{ACKNOWLEDGEMENT}

The authors are grateful to Mansour Distribution Company (Siclam Factory), for pro- viding experimental facilities and laboratory support. The authors particularly acknowledge the continuous support of Eng. Ahmed Khamis Juice Department Manager and special acknowledgement is due to Mr. Ossama Tawfik, Quality control manager.

\section{REFERENCES}

Abou-Zaid, M.A., El-Saied A.A. \& Akar,A. 1990. Technological studies on low calorie apricot nector. Bull.Nutr. Inst. Cairo, Egypt. 10:6573.

Anderson,J. \& Young, L. 2002. Sugar and sweeteners. C.F.//www. http: colostate.edu/.

A.O.A.C. 1990. Official Methods of Analysis of the Association of Official Analytical Chemists. Arlington, Virginia, 22201 U.S.A.

Askar, A. 1988. A review on sweeteners. El Nahurung Nut.12 .Nr. 11:706

Barwal, V.S., Sharma, R. \& Lal, B.B. 2002. Use of sorbitol for the preparation of plum seasoned squash. J. of Food Sci. \& Technol. 39: 413417.

Brandle, J.E. \& Rosa, N. 2003. Heritability for yield, leaf: steam ratio and stevioside content estimated from a landrace cultivar of stevia 
rebaudiana C.F.http://res2.agr.ca/Lon-don/ foq/stevia-e.htm.

Cardello, H.M., Da Silva, M.A. \& Damasio, M.H. 1999. Measurement of the relative sweetness of stevia extract, aspartame and cyclamate / saccharin blends as compared to sucrose at different concentrations. Plants Foods Hum Nutr. 54: 119 - 130.

Chan, P., Tomlinson, B., Chen, Y.J., Liu, J.C., Hsich, M.H. \& Cheng, J.T. 2000. A doubleblind placebo-controlled study of the effectiveness and tolerability of oral stevioside in human hypertension. Br. J. Clin Pharmacol. 50: 215 - 220 .

Dziezak, J.D. 1987. Crystalline fructose: A breakthrough in corn sweetener process technology. Food Technol. 41: 66-72.

Frank, R.A., Mize, S.J.S.\& Carier, R. 1989. An assessment of binary mixture interactions for nine sweetener. Chem. Senes. 14:623-632

Gelardi,R.C. 1987. The multiple sweetener approach and new sweeteners on the horizon. Food Technol. 41:123-124.

Geuns, J.M.C. 2002. Safety evaluation of stevia and stevioside. In: Atta-ur R. (ed). Studies in Natural Products Chemistry, vol. 27:1 Bioactive Natural Products (Part H). Elsevier, Amesterdam, pp. 299-319.

Geuns, J.M.C. 2003. Stevioside. Phytochem. 64: 913-921.

Hanger, L.Y., Lotz, A.\& Lepeniotis, S. 1996. Descriptive profiles of selected high intensity sweeteners (HIS), HIS blends and sucrose. J. Food Sci. 61: 456-459.

Hassan, I. Mona, Zeitoun, A.A., Zeitoun, A,M., \& Moussa, M.M. 2002. Effects of harvesting time, drying, extraction and purification methods on sweeteners extracted from stevia rebaudiana Bertoni. J. Agric. Sci. Mansoura. 27: 323- 339 .

Horne, J., Lawless, H.T., Speirs, W. \& Sposato, D. 2002. Bitter taste of saccharin and acesulfame - K. Chem. Senses. 27: $31-38$.

Hutteau, F., Mathlouthi, M., Portmann, M.O. \& Kilcast, D. 1998. Physico-chemical and psychophysical characteristics of binary mixtures of bulk and intense sweeteners. Food Chem. 63:9-16.

Huxtable, R.J. 2002. Pharmacology and toxicology of stevioside, rebaudioside A and steviol. In Kinghorn. A.D. (ed.). Stevia, the genus stevia. Medicinal and Aromatic Plants. Industrial Profiles, vol. 19. Taylorand Francis. London and NY pp. 160-177.

Jeppesen, P.B., Gregersen, S., Poulsen, C.R. \& Hermansen, K. 2000. Stevioside acts directly on pancreatic beta cells to secrete insulin: ac- tions independent of cyclic adenosine monophosphate and adenosine triphosphate - sensitive $\mathrm{K}^{+}$Chennel activity. Metabolism. 49: 208-214.

Kim, J., Choi, Y.H. \& Choi, Y.H. 2002. Use of stevioside and cultivation of Stevia rebaudiana in Korea. In: Kinghorn, A. D.(ed) Medical and Aromatic Plants-Industrial Profiles. Vol.19 Taylor and Francis. London and NY, pp. 196-202.

Kinghorn, A.D. 2002. Overview. In: Kinghorn, A. D. (ed), Stevia, the Genus Stevia. Medical and Aromatic Plants-Industrial Profiles. Vol.19 Taylor and Francis. London and NY, pp 1-17.

Kuhn, C., Bufe, B., Winning, M., Hofmann, T., Frank, O., Behrens, M. Lewtschenko, T., Slack, J., Ward, C.D. \& Meyerhof, W. 2004. Bitter taste receptors for saccharin and acesulfame k. J. Neuro Sci. 24: 10260-10265.

Lipinski, G.W. 1986. Acesulfame-k. In Alternative Sweeteners. O'Brien, N. and Gelardi, R. (eds), Marcel Dekker, Inc:NewYork,Basel.

Matysiak, N.L. \& Noble, A.C. 1991. Comparison of temporal perception of fruitiness in model systems sweetened with aspartame and aspartame +acesulfame $\mathrm{k}$ blend or sucrose . J Food Sci. 56:823-826.

Matz, A.S. 1962. Food Texture. The AVI Publishing Company, INC., Westport, Connecticut. pp.26-27.

Moussa, M.M., Zeitoun, A.M., Zeitoun, A.A., \& Hassan, I. Mona. (2003). Physicochemical properties of stevia sweeteners as natural low caloric sweetener. Alex. J. Agric. Res. 48: 61-75.

Nahon, D.F., Roozen, J.P. \& Graaf, G. 1996. Sweetness flavour interactions in soft drinks. Food Chem. 56: 283-289.

Ott, D.B., Edwards, C.L. \& Palmer, S. J. 1991. Perceived taste intensity and duration of nutritive and non-nutritive sweeteners in water using time - intensity (T-1) evaluations. J. Food Sci. 56:535 - 541.

Pszczola, D.E. 2003. Sweetener and sweetener enhances the equation. Food Tech. 57: 48-51.

Rangana, S. 1977. Manual of Analysis of Fruit and Vegetable Products. McGrow-Hill Pub. Co. Ltd., New Delhi.

Sadasivam, S. \& Manickam, A. 1992. Determination of Fructose and Inulin. Agric. Scie., Wiley Eastern Ltd., New Delhi, India.

Schiffman, S.S., Valerie, A., Crofton, B.\& Timothy, G.B. 1985. Sensory evaluation of soft drinks with various sweeteners .Physiology \& Behavior. 34: 369-377. 
Schiffman, S.S., Booth, B.J., Carr, B.T., Losee, M.L., Sattely-Miller, E. \& Graham, B.G. 1995. Investigation of synergism in binary mixtures of sweeteners. Brain Res. Bull. 38: $105-120$.

Schiffman, S.S., Sattely-Miller, E.A., Graham, B.G, Zervakis, J.,Butchko, H.H.\& Stargel, W.W. 2003. Effect of repeated presentation on sweetness intensity of binary and ternary mixtures of sweeteners. Chem Senses. 28: 219-29.

Steel, R.G. \& Torrie, J.H. 1980. Principles and Procedures of Statistics. Mc Graw-Hill Book Co., Inc. New York, USA.

Von Rymon, G.W. 1997. The blending of sweeteners-applications and safety issues. In Grenby, T.H. (ed). Advances in Sweeteners. Blackie Academic \& Professional an imprint of Chapman \& Hall, Londan, pp. 263-272

Watts, B.M., Yanaki, G.L., Jeffery, L.E.\& Elias, L.G. 1989. Basic Sensory Methods for Food
Evaluation. $1^{\text {st }}$ Edition. The international Development Research Center Publ., Otawa, Canada.

Weihrauch, M.R. \& Diehl, V. 2004. Artificial sweeteners-do they bear a carcinogenic risk?. Annals of Oncology. 15:1460-1465.

Wiet, S.G. \& Beyts, P.K. 1992. Sensory characteristics of sucralose and other high intensity sweeteners. J. Food Sci. 57:1014 - 1019.

WHO Food Additives, 1999. Series 42: Safety evaluation of certain food additives. "Stevioside". Genf. pp. 119-143.

Xili,L., Chengjiany, B., Eryi, X., Reiming, S., Yuengming, W. Hao-dong, S. \& Zhiyian, H. 1992. Chronic oral toxicity and carcinogenicity study of stevioside in rats. Food Chem.Toxical. 30: 957-965.

\section{التأثيرات المؤازرة لبعض المحليات البليلةهلى الصفات غير المرغوبة لمحلى الأستفيا وتطبيقاتها فى بعض مشروبات الثاكهة}

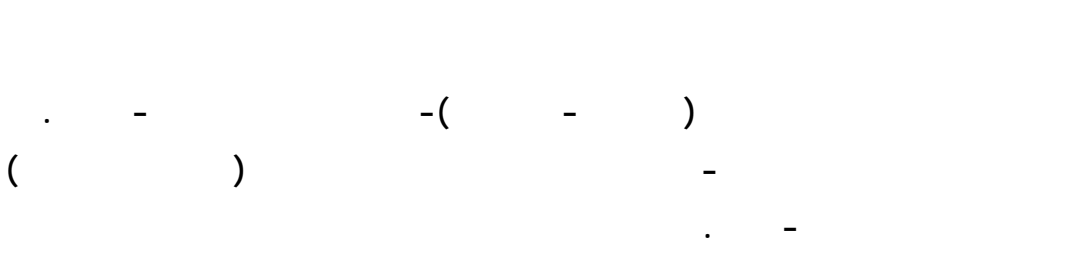

يتميز محله الأسفيا بدرجه عالية من الحلاوة إلا أن له طعماً مراً وطعوماً لخرى غير ممرغوبة فى حالة

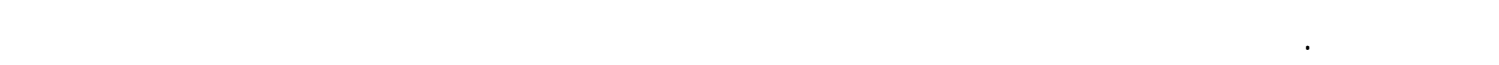

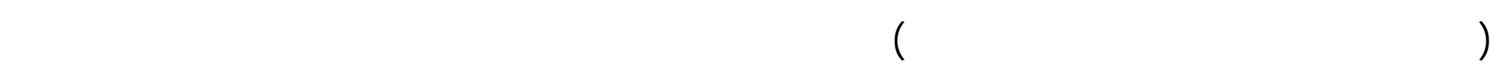

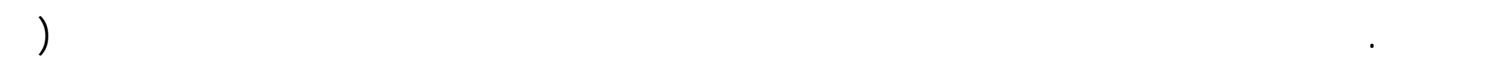

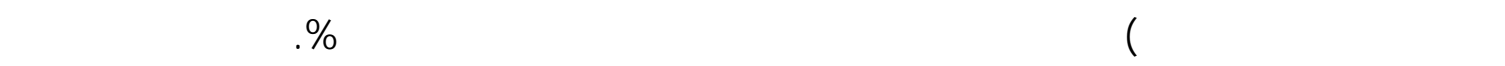

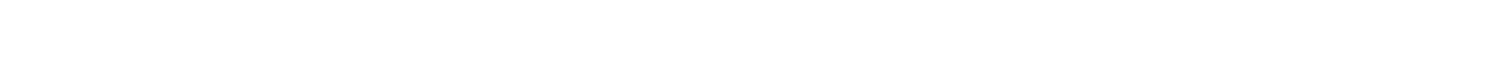

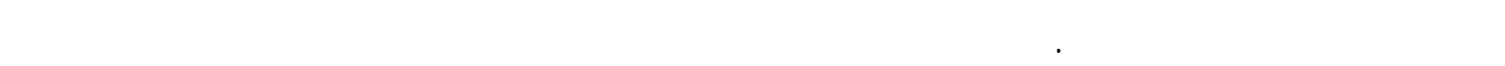

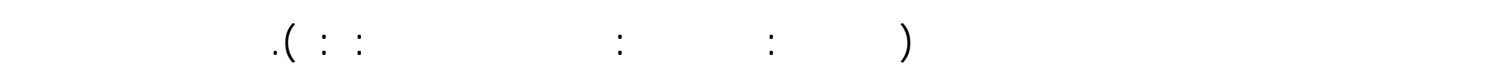

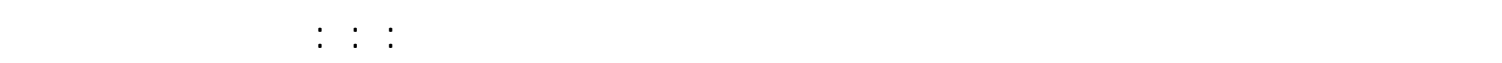

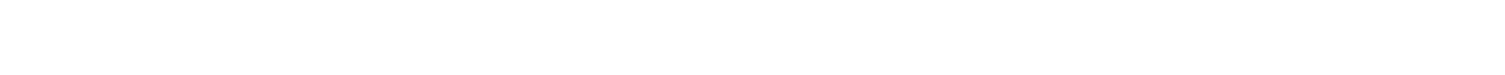

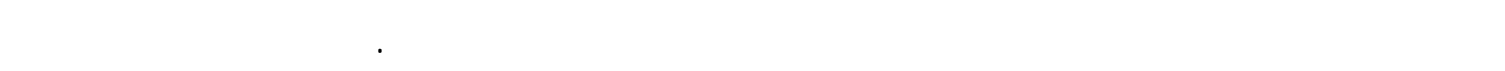

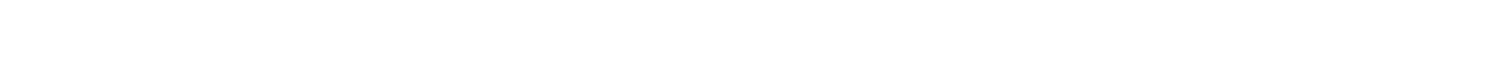

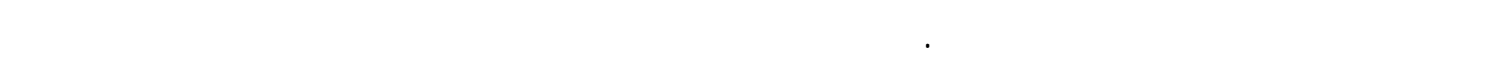

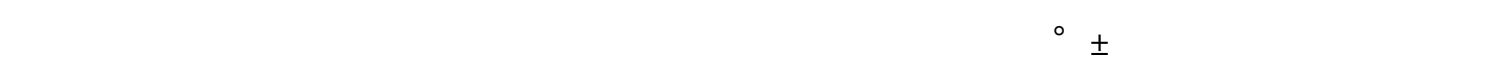

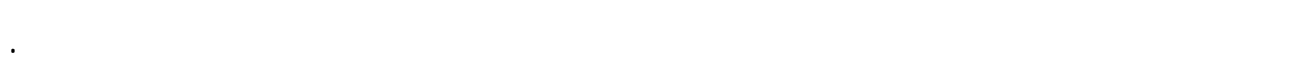

